\title{
Introduction of Odontoglossum ringspot virus Coat Protein Gene into Cymbidium niveo-marginatum mediated by Agrobacterium tumefaciens to Produce Transgenic Plants
}

\author{
Li Chen ${ }^{1}$, Hitomi Kawai ${ }^{1}$, Takashi Oku ${ }^{1}$, Chisako Takahashi ${ }^{2}$ and Yoshiyuki Niimi ${ }^{1 *}$ \\ ${ }^{1}$ School of Bioresources, Hiroshima Prefectural University, Shobara 727-0023, Japan \\ ${ }^{2}$ Mukaijima Orchid Center, Mukaijima, Hiroshima 722-8510, Japan
}

\begin{abstract}
We cloned the Odontoglossum ringspot virus (ORSV) coat protein (CP) gene from ORSV-infected Epidendrum and constructed a pHPUNOJ $\mathrm{E}^{-1}$ vector by ligating this $\mathrm{CP}$ gene, green fluorescence protein (GFP) gene, and hygromycin resistant $\left(\mathrm{Hyg}^{\mathrm{r}}\right)$ gene into the plasmid pGreenII. This chimeric vector was mediated into A. tumefaciens LBA 4404. By infecting and co-culturing the rhizomes of Cym. niveo-marginatum with $A$. tumefaciens LBA 4404, ORSV CP gene transgenic shoots were obtained. GFP was observed in $64 \%$ of the 81 surviving rhizomes and in $39 \%$ of 215 regenerated shoots. The presence of ORSV CP, GFP, and $\mathrm{Hyg}^{\mathrm{r}}$ genes was confirmed in the transgenic shoots by using polymerase chain reaction (PCR) analysis, whereas that of ORSV CP was confirmed by enzyme-linked immunosorbent assay (ELISA).
\end{abstract}

Key Words: Agrobacterium, cloning, Cymbidium, ORSV CP gene, transformation.

\section{Introduction}

In orchidaceous plants, Odontoglossum ringspot virus (ORSV) is especially prevalent and is distributed throughout the world (Erlinda and Benigno, 1983; Francki, 1966; Gibbs et al., 2000; Wisler et al., 1979; Zettler et al., 1990). ORSV was detected in 31 genera of orchid (Inouye, 2001). Inouye (1984) reported that even after soaking the 34 excised meristems $(0.1-0.3 \mathrm{~mm}$ size) infected by ORSV in its antiserum, he only obtained 18 virus-free cultures. It is not possible to put this method to practical use because there is no effective means of preventing ORSV disease from infecting orchids.

Cross-protection with a mild strain of a given virus reduces the susceptibility of a plant to more virulent strain of the same virus (Zaitlin, 1976). This mechanism has been used to create virus-resistant plants by producing virus coat proteins (CP). Powell-Abel et al. (1986) obtained tobacco-mosaic-virus-resistant plants and Van Dun and John (1988) also obtained tobaccorattle-virus-resistant plants by transforming their $\mathrm{CP}$ gene. Tumer et al. (1987) and Yoshioka et al. (1992) obtained transgenic tomato and melon plants with the $\mathrm{CP}$ genes of the alfalfa mosaic virus and cucumber mosaic virus, respectively. Resistance to each of these viruses has also been observed in the transgenic plants. Moreover, in a summary of 125 articles by Nishizawa et al. (1999), $52 \%$ of the plants that possess CP gene

Received; June 22, 2005. Accepted; October 12, 2005.

* Corresponding author (E-mail: niimi@pu-hiroshima.ac.jp). provided virus tolerance to the transformed bodies.

The CP gene of ORSV has already been sequenced (Ajjikuttira et al., 2002; Chng et al., 1996; Dubs and Van Regenmortel, 1990; Hilf and Dawson, 1993; Ikegami et al., 1995; Isomura et al., 1991; Ryu and Park, 1995). However, there has been no report on the CPmediated transgenic orchidaceous plants. Here, we report the production of ORSV CP in the transgenic plants of Cymbidium niveo-marginatum for the first time.

\section{Materials and Methods}

\section{Cloning of the ORSV CP gene}

The total RNA of an ORSV-infected Epidendrum (E. pink Ball, known as $\mathrm{J}_{\mathrm{E}}$ ), which was cultured in the Hiroshima Mukaishima Orchid Center, was extracted and cleaned by using the RNeasy Plant Mini Kit, according to the manufacturer's instructions (QIAGEN, Germany). The DNA fragments of ORSV CP were obtained by RT-PCR (RT-PCR Kit: Rever Tra Dash ${ }^{\mathrm{TM}}$, TOYOBO, Japan) by using the total RNA with the reverse primer, 5'-CGC GAT ATC TTA GGA AGA GGT CCA AGT-3' and the forward primer, 5'-CCA GGA TCC ATG TCT TAC ACT ATT ACA G-3', which was designed to be based on the sequence reported by Isomura et al. (1991). These DNA fragments were inserted into the BamH I and Sma I sites of a Glutathione S-transferase (GST) recombinant protein expression vector pGEX-6P-3 (Applied Biosystems, USA). This chimeric vector was named pHPUN001 and transformed into Escherichia coli (E. coli) DH $5 \alpha$ cells. 
Expression of ORSV CP gene in E. coli DH $5 \alpha$ cells by Western blotting analysis

The colonies of E. coli DH5 $\alpha$ cells that harbor the pHPUN001 were cultured to produce GST-ORSV CP recombinant protein in the LB medium according to the manual of Amersham Pharmacia Biotech. The suspension cultures were vortexed gently with BugBuster Protein Extraction Reagent (Novagen, USA) for $40 \mathrm{~min}$ at room temperature to destroy the cell walls of the $E$. coli $\mathrm{DH} 5 \alpha$. The re-centrifuged supernatants were purified by a MicroSpin ${ }^{\text {TM }}$ GST Purification Module (Amersham Pharmacia Biotech, USA). The recombinant protein was treated with PreScission Protease (Amersham Pharmacia Biotech) at $5^{\circ} \mathrm{C}$ for $16 \mathrm{~h}$ to cleave ORSV $\mathrm{CP}$ from the GST fusion proteins. The electrophoresis of the recombinant proteins was carried out by using the PAGEL-Compact (Atto Corp., Tokyo, Japan). The separated bands were transferred to the nylon membrane by using the TE 70 Series SemiPhor Semi-Dry Transfer Unit (Amersham Pharmacia Biotech). Western blotting analysis was carried out by reacting the ORSV antiserum with a conjugate $\mathrm{IgG}$ that originated from a rabbit (Japan Plant Protection Association Laboratory).

\section{Sequencing of the ORSV CP gene}

After being screened by Western blotting analysis, the pHPUN001 DNA of 9 clones that reacted with the ORSV antiserum was extracted and purified by the polyethylene glycol precipitating method. Then, PCR of ORSV CP gene, by using puReTaq ${ }^{\mathrm{TM}}$ Ready-To-Go ${ }^{\mathrm{TM}}$ PCR Beads (Amersham Pharmacia Biotech), was carried out by utilizing the $\mathrm{pUC} / \mathrm{M} 13$ forward and reverse primers (Promega, USA). The PCR products were sequenced with the BigDye ${ }^{\mathrm{TM}}$ Terminator Cycle Sequencing Ready Reaction Kit and ABI PRISM ${ }^{\mathrm{TM}} 310$ Genetic Analyzer (Applied Biosystems).

Structuring the plasmid vector pGreen II-CaMV $35 S$ GFP-CaMV 35S ORSV CP-NOS Hygr (pHPUNOJ ${ }^{-1}$ )

ORSV CP gene from the start codon to the stop codon was used for structuring the plasmid vector. All the other genes used for structuring the plasmid vector, such as nopaline synthase (NOS) promoter, pGreen II vector, green fluorescence protein (GFP), hygromycin resistance $\left(\mathrm{Hyg}^{\mathrm{r}}\right)$, cauliflower mosaic virus (CaMV) $35 \mathrm{~S}$ promoter, and CaMV 35S-GFP, NOS-Hyg ${ }^{\mathrm{r}}$ were obtained from John Innes Centre (UK).

With the forward primer 5'(BamH I)-CCA GGA TCC
ATG TCT TAC ACT ATT ACA G-3' and the reverse primer 5'(EcoR V)-CGC GAT ATC TTA GGA AG GGT CCA AGT-3', the BamH I and EcoR V sites were added to both ends of ORSV CP gene by the PCR method, by using pHPUN001 as the template. Then, the ORSV CP gene was ligated to the BamH I and Sma I sites of the CaMV35S promoter vector. The structured vector was named pHPUN002.

Through ligating CaMV35S-GFP gene to the Hpa I site of the pGreen II vector, a new vector, named pHPUN003 (pGreen II-CaMV 35S-GFP) was obtained. Then, by ligating CaMV 35S-ORSV CP gene to the Xho I and Apa I sites of pHPUN003 vector, another vector named pHPUN004 (pGreen II-CaMV 35S GFP-CaMV 35S ORSV CP) was obtained. At the end, by ligating the NOS-Hyg to the Stu I site of vector pHPUN004, the plasmid vector $\mathrm{pHPUNOJ}_{\mathrm{E}^{-1}}$ was obtained (Fig. 1).

\section{Making of Agrobacterium tumefaciens LBA4404 (pAL4404, pSoup, pHPUNOJ $E^{-1}$ )}

Because the plasmid pGreen requires the function of the RepA gene from plasmid pSoup to replicate it successfully in Agrobacterium species (Hellens et al., 2000), the plasmid pSoup was transformed into $A$. tumefaciens LBA 4404 (pAL 4404) by the Triparental mating method (Ditta et al., 1980). Then, the pHPUNOJ $_{\mathrm{E}^{-1}}$ vector was transformed into the $A$. tumefaciens LBA 4404 (pAL 4404, pSoup) by the same method, and the A. tumefaciens LBA 4404 (pAL 4404, pSoup, pHPUNOJ $\mathrm{E}^{-1}$ ) was obtained.

\section{Transforming the ORSV CP gene to Cym. niveo- marginatum}

Excised rhizome sections (136) of Cym. niveomarginatum were cultured with $A$. tumefaciens LBA 4404 (pAL 4404, pSoup, pHPUNOJ $\mathrm{E}^{-1}$ ) for two days in $\mathrm{LB}$ solid medium containing $25 \mathrm{mg} \cdot \mathrm{L}^{-1}$ streptomycin, $5 \mathrm{mg} \cdot \mathrm{L}^{-1}$ tetracycline, and $25 \mathrm{mg} \cdot \mathrm{L}^{-1}$ hygromycin (Hyg) at $28^{\circ} \mathrm{C}$. Infection and co-cultivation were carried out according to Chen et al. (2002). Subsequently, the rhizome sections were cultured in MS solid medium with $5 \mathrm{mg} \cdot \mathrm{L}^{-1}$ Hyg and $2 \mathrm{mg} \cdot \mathrm{L}^{-1}$ 6-benzyladenine (BA) for one month to induce transformed shoots.

\section{Confirming the expression of GFP}

The regenerated explants were observed for GFP with an OLYMPUS BX50WI-Macro RFL fluorescent microscope (OLYMPUS Corp., Tokyo, Japan). The

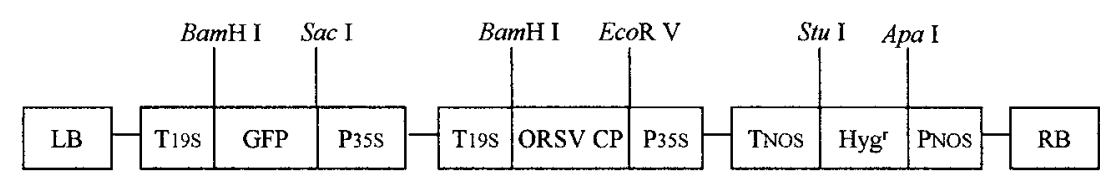

Fig. 1. Schematic structure of the T-DNA region in the plasmid pHPUNOJ $\mathrm{E}^{-1}$. LB, Left border; T19S, terminator of CaMV 19S; GFP, the coding region of GFP gene; P35S, CaMV 35S promoter; ORSV CP, the coding region of ORSV CP gene; TNOS, nos terminator; Hyg ${ }^{r}$, the coding region of $\mathrm{Hyg}^{\mathrm{r}}$ gene; PNOS, nos promoter; RB, right border. 


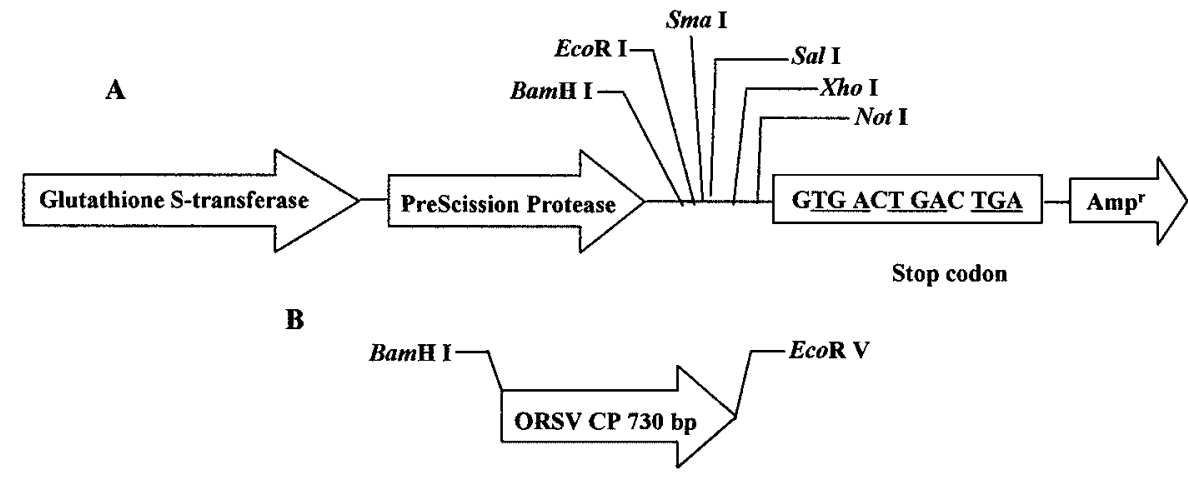

Fig. 2. The GST recombinant protein region of pGEX-6P-3 vector (A) and fragment of ORSV CP gene (B). ORSV CP gene was inserted into BamH I and Sma I sites of GST recombinant protein region.

wavelength of occurring light is $510 \mathrm{~nm}$ and that of filter excitation light is $460-490 \mathrm{~nm}$.

\section{Confirming the transformed genes}

Six shoots were selected at random from the other transgenic shoots in which the expression of GFP was observed by fluorescent microscope, except the 2 shoots used for DAS-ELISA described as follows. The 6 shoots (total weight about $0.5 \mathrm{~g}$ ) were macerated and the total DNA extracted for PCR. The forward primer $5^{\prime}(\operatorname{BamH}$ I)-CCA GGA TCC ATG TCT TAC ACT ATT ACA G$3^{\prime}$ with the reverse primer 5 '(EcoR V)-CGC GAT ATC TTA GGA AG GGT CCA AGT-3', the forward primer 5'-GGA TCC AAG GAG ATA TAA CAA TGA-3' with the reverse primer 5'-GAG CTC TTA TTT GTA TAG TTC ATC-3', and the forward primer 5'-TCT GTC GAG AAG TTT CTG ATC GAA-3' with the reverse primer 5'-GTT CTC TCG CAT TTG CCT TGC TA-3 were tested for the presence of ORSV CP, GFP and $\mathrm{Hyg}^{\mathrm{r}}$, respectively.

Double antibody sandwich enzyme-linked immunosorbent assay (DAS-ELISA)

DAS-ELISA (Converse and Martin, 1990) was used to detect ORSV CP in 2 transgenic shoots in which GFP fluoresced most strongly. Samples of transgenic and nontransgenic shoots $(100 \mathrm{mg})$ were homogenized with $1 \mathrm{~mL}$ of PBS-T buffer ( $\mathrm{pH} 7.4$ ) that included $0.85 \% \mathrm{NaCl}$, $0.02 \% \mathrm{NaN}_{3}$, and $0.05 \%$ Tween 20 . The homogenate was centrifuged for $6 \mathrm{~min}$ at $3000 \mathrm{rpm}$ (Inouye, 2001). The supernatants $(200 \mu \mathrm{L})$ were added to each of 3 wells containing the ORSV CP antibody coating liquid (rabbit r-globulin, $0.05 \% \mathrm{NaN}_{3}$ ) and anti-rabbit $\mathrm{IgG}$ conjugate liquid (alkalinephosphatase rabbit r-globulin, 1\% cow serum albumin, and $0.05 \% \mathrm{NaN}_{3}$ ). The test was carried out as described by Takahashi (1988). The absorbance was measured at $405 \mathrm{~nm}$ with a JASCO UBest-30 UV/ VIS Spectrophotometer (JASCO, Tokyo, Japan).

\section{Results and Discussion}

\section{Cloning of ORSV CP gene}

The double-stranded DNA fragments of the $730 \mathrm{bp}$
ORSV CP were obtained by using RT-PCR of the total RNA of an ORSV-infected Epidendrum. They were purified and digested by the restriction enzymes of $B a m \mathrm{H}$ $\mathrm{I}$ and $E c o \mathrm{R} \mathrm{V}$ linked in both ends of the CP gene fragments, respectively. Then, by inserting the fragments into the BamH I and Sma I sites of a GST recombinant protein expression vector-pGEX-6P-3, the vector pHPUN001 (Fig. 2) was obtained.

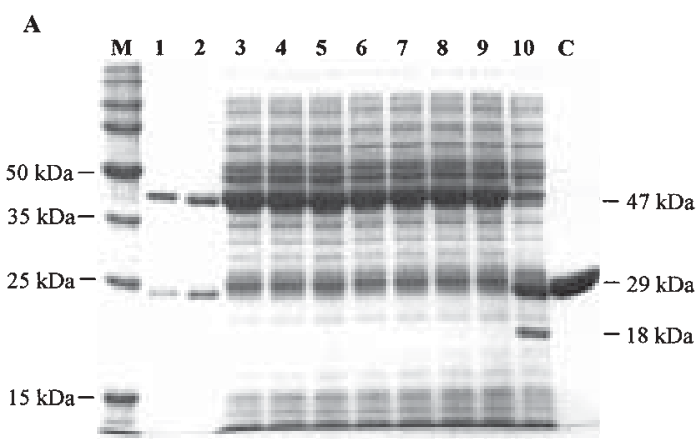

$\mathbf{B}$

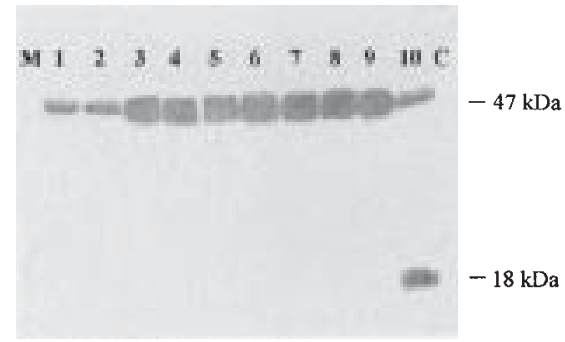

Fig. 3. Gel plates confirming the expression of GST-ORSV CP recombinant protein by SDS-PAGE analysis (A) and Western blotting analysis (B). M, $10-225 \mathrm{kDa}$ Coomassie blue perfect protein markers (Novagen); 1-9, lysates of 9 colonies of E. coli $\mathrm{DH} 5 \alpha$ cells harbouring pGEX-6P-3-ORSV CP gene, all of them produced the $47 \mathrm{kDa}$ GST-ORSV CP recombinant protein; 10 , liquid of lysate of number 9 colony after treating by PreScission Protease (29kDa, GST protein; $18 \mathrm{kDa}$, ORSV CP); C, control of lysate of $E$. coli $\mathrm{DH} 5 \alpha$ cells harbouring pGEX-6P-3 vector (29 kDa, GST protein). 
Expression of CP gene in E. coli DH 5 a cells by Western blotting analysis

To confirm the expression of $\mathrm{CP}$ gene by Western blotting analysis, the pHPUN001 were transformed into E. coli DH $5 \alpha$ cells. The 9 colonies of E. coli $\mathrm{DH} 5 \alpha$ cells were transformed by the pHPUN001 also expressed the $47 \mathrm{kDa}$ recombinant proteins (Fig. 3A, lanes 1-9). When the recombinant proteins were treated with PreScission Protease at $5^{\circ} \mathrm{C}$ for $16 \mathrm{~h}$, the $18 \mathrm{kDa}$ ORSV CPs were cleaved from the GST fusion proteins (Fig. $3 \mathrm{~A}$, lane 10). All of the GST-ORSV CP recombinant proteins of the 9 colonies and ORSV CP reacted with the ORSV antiserum (Fig. 3B), indicating that the pHPUN001 was transformed into the 9 colonies of $E$. coli DH $5 \alpha$ containing the ORSV CP gene. Therefore, the ORSV CP genes from all 9 colonies were used for sequencing.

\section{Sequence of ORSV CP gene}

The sequences of the $730 \mathrm{bp}$ ORSV CP genes derived from two colonies were in $100 \%$ correspondence. Those of the other 7 colonies attained $98-99 \%$ correspondence with each other. Furthermore the sequences of the $477 \mathrm{bp}$ from the start to stop codons of all 9 colonies were identical. In this range, the correspondences were $99.58 \%, 99.37 \%, 99.37 \%, 99.79 \%$, and $99.58 \%$ with the sequences isolated in France (Type-Strain, called it as $\mathrm{F}_{\mathrm{TS}}$, Dubs and Van Regenmortel, 1990), Japan (Cy-1, $\mathrm{J}_{\mathrm{Cy}-1}$, Isomura et al., 1991), the U.S. (TMV-O, A $\mathrm{A}_{\mathrm{TMV}-}$ o, Hilf and Dawson, 1993), Korea (Cy, $\mathrm{K}_{\mathrm{Cy}}$, Ryu et al., 1995), and Singapore ( $S_{1}$, Chng et al., 1996), respectively (Fig. 4A). Their deduced amino acid sequences were in $100 \%$ correspondence (Fig. 4B), showing that the rate of ORSV mutation is universally low. Thus, the transformed orchid with the CP gene of the one strain of ORSV, which was obtained by gene transformation, seemed to be resistant to all other strains of ORSV.

Survival rate of transformed explants selected by Hyg

When the infected rhizome sections were cultured for a month on MS solid medium, containing $5 \mathrm{mg} \cdot \mathrm{L}^{-1} \mathrm{Hyg}$ and $2 \mathrm{mg} \cdot \mathrm{L}^{-1} \mathrm{BA}, 81$ rhizome sections out of a total of $136(59.7 \%)$ survived. From the 81 rhizome sections, 227 shoots were induced of which $215(94.6 \%)$ survived.

$\mathbf{A}$
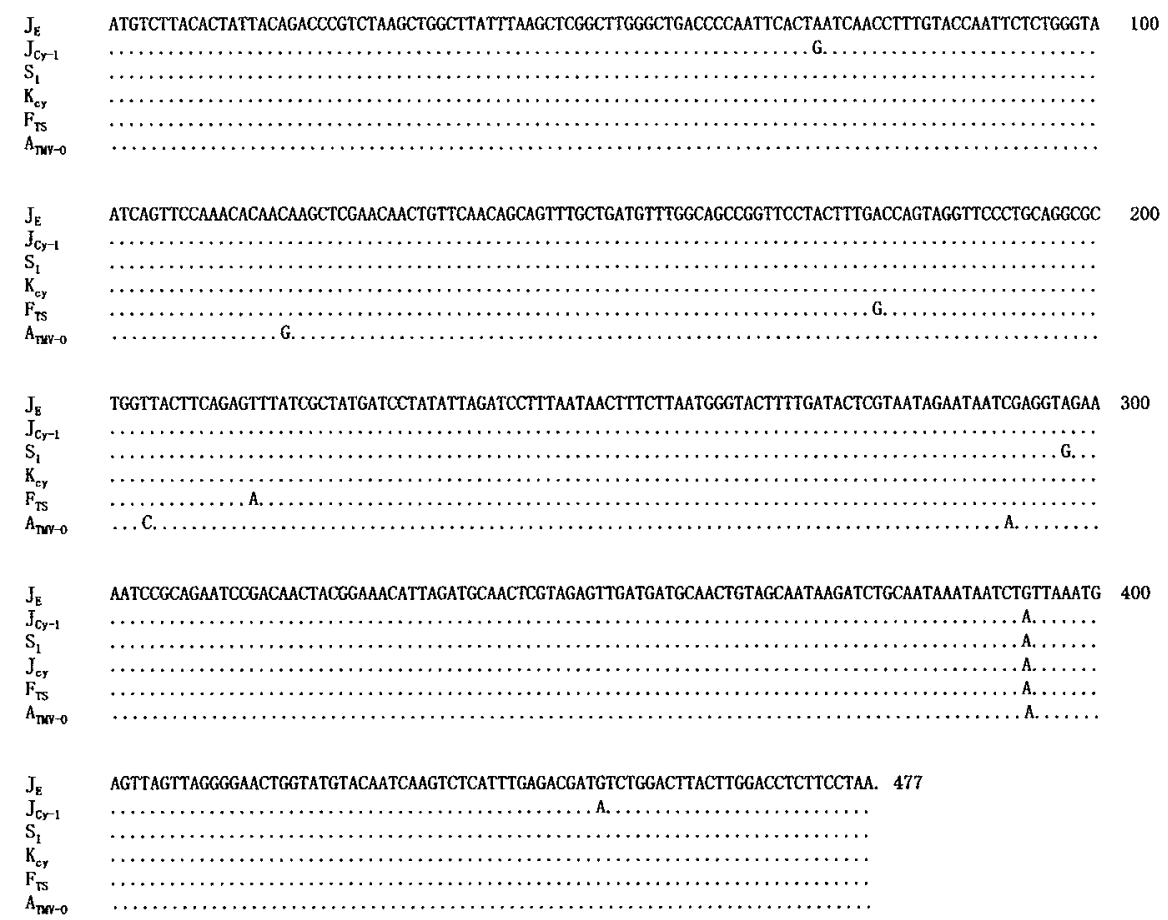

B

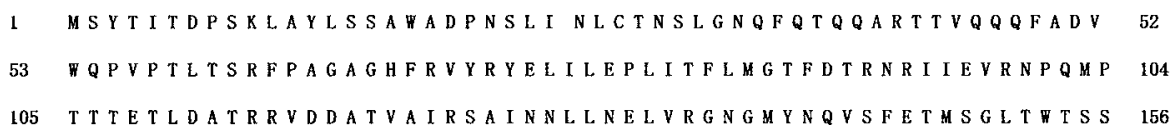

Fig. 4. Comparison of the nucleotide sequence of ORSV- $\mathrm{J}_{\mathrm{E}}$ coat protein from start codon to stop codon with those of other five strains (A) and deduced amino acid sequence of ORSV CP gene (B). $\mathrm{J}_{\mathrm{E}}$, analyzed by us in this time isolated from an ORSV-infected Epidendrum in Japan; $\mathrm{J}_{\mathrm{Cy}-1}$, reported by Isomura et al (1991) isolated from Cy-1 strain in Japan; $\mathrm{S}_{1}$, reported by Chng et al (1996) isolated from a Singapore strain; $\mathrm{K}_{\mathrm{Cy}}$, reported by Ryu et al (1995) isolated from Cy strain in Korea; $\mathrm{F}_{\mathrm{TS}}$, reported by Dubs and Van Regenmortel (1990) isolated from TypeStrain; A TMV-O$_{\text {, }}$ reported by Hilf and Dawson (1993) isolated from TMV-O strain. 
Confirming the expression of GFP by using a fluorescent microscope

The GFP was observed in 52 of $81(64 \%)$ surviving rhizomes, whereas it was observed in 84 of $215(39 \%)$ of the regenerated shoots. The expression of GFP appeared strong in 5 rhizome sections and shoots that were induced from these rhizomes. However, in the remaining 47 sections, the expression of GFP appeared only in some parts of the rhizome or induced shoots.

\section{Size confirmation of the transformed genes by PCR}

The sizes of all transformed genes were confirmed by PCR (Fig. 5) that for GFP was about $750 \mathrm{bp}$, whereas that of ORSV CP was about 500 bp from the start codon to stop codon and adding restriction enzymes sites of BamH I and EcoR V, while that of $\mathrm{Hyg}^{\mathrm{r}}$ was about $1000 \mathrm{bp}$.

\section{Double antibody sandwich enzyme-linked immuno-} sorbent assay (DAS-ELISA)

The liquid absorbance value of transgenic plant I (TI) was $0.526 \pm 0.099$, that of transgenic plant II (TII) was $0.682 \pm 0.108$, and that of untransformed control plant (C) was $0.182 \pm 0.037$, so, $2 \mathrm{C}<\mathrm{TI}<3 \mathrm{C}<\mathrm{TII}$. Thus, the absorbance values of TI and TII were 2.89 and 3.47 times that of the control, respectively. Takahashi (1988) examined 81 research theses, in which ELISA was used, found that if the absorbance value of the transformation body was twice or more than that of the non-transformed body, the protein appeared to possess the transformed gene. According to this, the ORSV CP gene obtained in this research was transformed.

It is known that ORSV reduces the economic value of orchidaceous plants. There is no effective means of preventing ORSV disease, but since the late 1980s many virus-resistant plants have been created by producing and expressing $\mathrm{CP}$ by transforming the $\mathrm{CP}$ gene. In orchidaceous plants, Anzai et al. (1996), Belarmino and Mii (2000), Chia et al. (1994), Kuehnle and Sugii (1992),

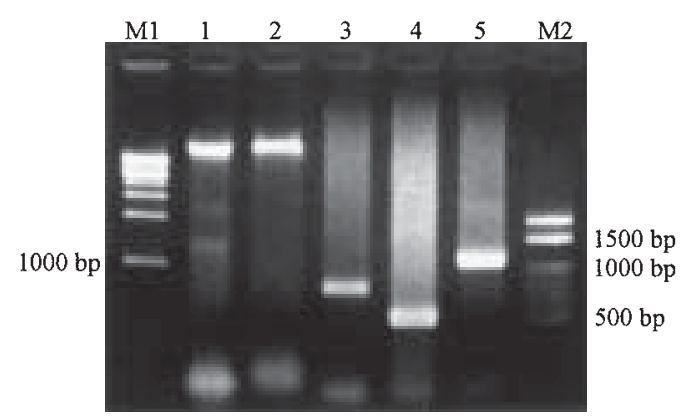

Fig. 5. A gel plate confirming the transformed genes by PCR. M1 and M2, size marker gene; 1, transgenic shoots genome DNA; 2, transgenic shoots genome DNA after treating by Apa I and Xho I; 3, PCR products of transgenic shoots genome DNA with GFP primers; 4, PCR products of transgenic shoots genome DNA with ORSV CP gene primers; 5, PCR products of transgenic shoots genome DNA with $\mathrm{Hyg}^{\mathrm{r}}$ gene primers.
Yang et al. (1999), and Yu et al. (1999) isolated the $\beta$ glucuronidase (GUS) or firefly luciferase gene transformants of Phalaenopsis, Cymbidium or Dendrobium, whereas Knapp et al. (2000) produced the bar gene transformants of Brassia, Cattleya and Doritaenopsis. More recently, Chen et al. (2002), Niimi et al. (2001a, b) developed the GUS transformants of Neofinetia falcate $\mathrm{Hu}$ and Cym. niveo-marginatum Makino, while Yu et al. (2001) did the same with Dendrobium with the class 1 Knox gene DOH1. Liau et al. (2003) also obtained the sweet pepper ferredoxin-like protein ( $p f l p)$ transformants of Oncidium, that conferred resistance against soft rot disease. Liao et al. (2004) was successful in obtaining transgenic Phalaenopsis possessing the CP of Cymbidium mosaic virus. Currently, however, very few reports deal with transgenic engineering in orchidaceous plants, one of the larger families of plants. In this research, we tried to create ORSV-resistance orchidaceous plants by transforming the ORSV CP gene. It seems that we confirmed the presence of the ORSV CP gene and ORSV $\mathrm{CP}$ in the transformed shoots of Cym. niveo-marginatum by PCR and ELISA methods, respectively. We hope to continue this research on the resistance to ORSV and its inheritance by new hybrid progenies.

\section{Literature Cited}

Ajjikuttira, P. A., C. L. Lim-Ho, M. H. Woon, K. H. Ryu, C. A. Chang, C. S. Loh and S. M. Wong. 2002. Genetic variability in the coat protein genes of two orchid viruses: Cymbidium mosaic virus and Odontoglossum ringspot virus. Arch. Virol. 147: 1943-1954.

Anzai, H., Y. Ishii, M. Shichinohe, C. Nojiri, H. Morikawa and M. Tanaka. 1996. Transformation of Phalaenopsis by particle bombardment. Plant Tissue Cult. Lett. 13: 265-272.

Belarmino, M. M. and M. Mii. 2000. Agrobacterium-mediated genetic transformation of a Phalaenopsis orchid. Plant Cell Rep. 19: 435-442.

Chen, L., T. Hatano and Y. Niimi. 2002. High efficiency of Agrobacterium mediated transformation by using rhizome of Cymbidium (Orchidaceae: Maxillarieae). Lindleyana 17: 16-20.

Chia, T. F., Y. S. Chan and N. H. Chua. 1994. The firefly luciferase gene as a non-invasive reporter in Dendrobium transformation. Plant J. 6: 441-446.

Chng, C-G., S-M. Wong, P. H. Mahtani, C-S. Loh, C-J. Goh, M. C-M. Chung and Y. Watanabe. 1996. The complete sequence of a Singapore isolate of Odontoglossum ringspot virus and comparison with tobamoviruses. Gene 171: 155-161.

Converse, R. H. and R. R. Martin. 1990. ELISA methods for plant viruses. p. 179-196. In: R. Hampton, E. Ball, and S. de Boer (eds.). Serological methods for detection and identification of viral and bacterial plant pathogens. Amer. Phytopathol. Soc. St Paul.

Ditta, G., S. Stanfield, D. Corbin and D. R. Helinski. 1980. Broad host range DNA cloning system for gram negative 
bacteria-construction of a gene bank of Rhizobium meliloti. Proc. Natl. Acad. Sci. U.S.A. 77: 7341-7351.

Dubs, M. C. and M. H. V. Van Regenmortel. 1990. Odontoglossum ringspot virus coat protein: sequence and antigenic comparisons with other tobamoviruses. Arch. Virol. 115: 239-249.

Erlinda, P. R. and D. A. Benigno. 1983. Chlorotic leaf streak of oncidium 'Golden shower'. The Philippine Agriculturist 66: 1-16.

Francki, R. I. B. 1966. Isolation, purification, and some properties of two viruses from cultivated cymbidium orchids. Aust. J. Biol. Sci. 19: 555-564.

Gibbs, A., A. Mackenzie, A. Blanchfield, P. Cross, C. Wilson, E. Kitajima, M. Nightingale and M. Clements. 2000. Viruses of orchids in Australia; their identification, biology and control. The Australian Orchid Rev. 65: 10 21.

Hellens, R., A. Edwards, N. R. Leyland, S. Bean and P. M. Mullineaux. 2000. pGreen, a versatile and flexible binary Ti vector for Agrobacterium-mediated plant transformation. Plant Mole. Boil. 42: 819-832.

Hilf, M. E. and W. O. Dawson. 1993. The tobamovirus capsid protein functions as a host-specific determinant of longdistance movement. Virol. 193: 106-114.

Ikegami, M., Y. Isomura, Y. Matumoto, M. Chatani and N. Inouye. 1995. The complete nucleotide sequence of odontoglossum ringspot virus (Cy-1 strain) genomic RNA. Microbiol. Immunol. 39: 995-1001.

Inouye, N. 1984. Making to nontoxic of virus infected Cymbidium by culturing growth point tissue and treating by antiserum. Agricul. Res. 60: 123-133.

Inouye, N. 2001. Detection, identification and control of virus diseases of orchids (In Japanese). Nobunkyo, Tokyo.

Isomura, Y., Y. Matumoto, A. Murayama, M. Chatani N. Inouye and M. Ikegami. 1991. Molecular cloning, sequecing and expression in Escherichia coli of the odontoglossum ringspot virus coat protein gene. J. Gener. Virol. 72: 2247-2249.

Knapp, J. E., A. P. Kausch and J. M. Chandlee. 2000. Transformation of three genera of orchid using the bar gene as a selectable marker. Plant Cell Rep. 19: 893-898.

Kuehnle, A. R. and N. Sugii. 1992. Transformation of Dendrobium orchid using particle bombardment of protocorms. Plant Cell Rep. 11: 484-488.

Liao, L-J., I-C. Pan, Y-L. Chan, Y-H. Hsu, W-H. Chen and M-T. Chan. 2004. Transgene silencing in Phalaenopsis expressing the coat protein of Cymbidium Mosaic Virus is a manifestation of RNA-mediated resistance. Mole. Breed. 13: 229-242.

Liau, C-H., J-C. Lu, V. Prasad, H-H. Hsiao, S-J. You, J-T. Lee, N-S. Yang, H-E. Huang, T-Y. Feng, W-H. Chen and M-T. Chan. 2003. The sweet pepper ferredoxin-like protein ( $p f l p)$ conferred resistance against soft rot disease in Oncidium orchid. Transgenic Res. 12: 329-336.

Niimi, Y., L. Chen and T. Hatano. 2001a. Gene transformation by using Agrobacterium in some orchidaceous plants. Proceed. 7th Asia Pacific Orchid Confer.: 95-98.

Niimi, Y., T. Hatano and L. Chen. 2001b. Micropropagation and Agrobacterium mediated genetic transformation of orchids. p. 427-435. In: Pathak, P., R. N. Sehgal, N. Shekhar, M. Sharma and A. Sood (eds.). Orchids Science and Commerce. M/s Bishen Singh Mahendra Pal Singh. Dehradun.

Nishizawa, Y., M. Suzuki and T. Hibi. 1999. Current status of the disease-resistant transgenic plants. Kagaku-toSeibutsu 37: 295-305 (In Japanese).

Powell-Abel, P., R. S. Nelson, B. De, N. Hofmann, S. G. Rogers, R. T. Fraley and R. N. Beachy. 1986. Delay of disease development in transgenic plants that express the tobacco mosaic virus coat protein gene. Science 232: 738 743.

Ryu, K. H. and W. M. Park. 1995. The complete nucleotide sequence and genome organization of odontoglossum ringspot tobamovirus RNA. Arch. Virol. 140: 1577-1587.

Takahashi, Y. 1988. Serological diagnosis of plant virus disease; (2) ELISA: feature and practical notes. Plant Protection 42: 88-92 (In Japanese).

Tumer, N. E., K. M. O'Connell, R. S. Nelson, P. R. Sanders, R. N. Beachy, R. T. Fraley and D. M. Shah. 1987. Expression of alfalfa mosaic virus coat protein gene confers cross-protection in transgenic tobacco and tomato plants. EMBO J. 6: 1181-1188.

Van Dun, C. M. P. and F. B. John. 1988. Transgenic tobacco plants accumulating tobacco rattle virus coat protein resist infection with tobacco rattle virus and pea early browning virus. Virol. 167: 649-652.

Wisler, G. C., F. W. Zettler and T. J. Sheehan. 1979. Relative incidence of cymbidium mosaic and odontoglossum ringspot viruses in several genera of wild and cultivated orchids. Proc. Florida State Hort. Soc. 92: 339-340.

Yang, J., H-J. Lee, D. H. Shin, S. K. Oh, J. H. Seon, K. Y. Paek and K-H. Han. 1999. Genetic transformation of Cymbidium orchid by particle bombardment. Plant Cell Rep. 18: 978-984.

Yoshioka, K., K. Y. Hanada, Y. Nakazaki, Y. T. Minobe, T. Yakuwa and K. Oosawa. 1992. Successful transfer of the cucumber mosaic virus coat protein gene to Cucumis melo L. Japan. J. Breed. 42: 277-285.

Yu, Z., M. Chen, L. Nie, H. Lu, X. Ming, H. Zheng, L-J. Qu and Z. Chen. 1999. Recovery of transgenic orchid plants with hygromycin selection by particle bombardment to protocorms. Plant Cell Tiss. Org. Cul. 58: 87-92.

Yu, H., S. H. Yang and C. J. Goh. 2001. Agrobcteriummediated transformation of a Dendrobium orchid with the class 1 Knox gene DOH1. Plant Cell Rep. 20: 301-305.

Zaitlin, M. 1976. Letter to the Editor. Viral cross protection: more understanding is need. Phytopathol. 66: 382-383.

Zettler, F. W., N-J. Ko, G. C. Wisler, M. S. Elliott and S-M. Wong. 1990. Viruses of orchids and their control. Plant Disease 74: 621-626. 
Agrobacterium tumefaciens による Odontoglossum ringspot virus 外皮タンパク質遺伝子導入玉花ランの作出

$$
\begin{aligned}
& \text { 陳 } \text { 莉 }^{1} \text { ・河合仁美 }{ }^{1} \text { 奥 尚 }{ }^{1} \text { 高橋智佐子 } \\
&
\end{aligned}
$$

Odontoglossum ringspot virus (ORSV) 外皮タンパク質 (CP) 遺伝子をウイルスに感染した Epidendrum からク ローニングし, green fluorescence protein (GFP) 遺伝子抒 よびハイグロマイシン抵抗性 $\left(\mathrm{Hyg}^{\mathrm{r}}\right)$ 遺伝子をプラスミ ドベクターpGreenII に組久込久, 植物発現ベクター pHPUNOJ $_{\mathrm{E}^{-1}}$ を構築した. プラスミド pHPUNOJ $\mathrm{E}^{-1}$ ベク ターを Agrobacterium tumefaciens LBA 4404 に導入し, 玉 花ラン (Cymbidium niveo-marginatum) ライゾームと共存 培養した. その結果, ハイグロマイシンセレクション 136
個のライゾーム中 81 個の生存を確認した。生存したラ イゾームから 227 個のシュートが発生し，その中で 215 個の生存を確認した. $64 \%$ の生存したライゾームおよび 39\%の生存したシュートから GFP 蛍光が観察された. GFP 蛍光が観察されたシュートから polymerase chain reaction (PCR) 法で ORSV CP, GFP, Hygr 遺伝子を検出 した. ORSV CP は enzyme-linked immunosorbent assay (ELISA) で確認した. 